\title{
ファジィ推論とその健康診断システムへの応用
}

○朝枝 哲也, 吉田 克己, 田中 健一
山田 親久,

〈はじめに〉様々なレベルにおける健診業務の自動 化が進められる中で, 特に最近の動向として, 健康指 導を支援するシステムの開発がいくつか報告されるよ うになり, 総合健診における情報処理の課題は, 量に 加えて質の時代に入ったと言える。すなわち，大量の デー夕をいかに迅速に適確に, 総合的に判定し得るか という自動診断（スクリーニング）の問題がクローズ アップされてきている。

自動診断の考え方は, 古くよりあり, これまでにも 枝分れ法, 出現頻度評価法, 距離法, 判別関数を用い た統計学的手法などの報告がある。又最近では, LISP, PROLOG な゙の人工知能言語によるエキスパート・ システムの開発があげられる。しかし，その名前から くる期待は大きいものの, 比較的限られた狭い領域の 診断技術に関するものが殆どで，健診のような general な判定領域に用いるには, なお演算速度の速いコ ンピュータの開発が待たれる。

一方，ファジィ推論の応用は，様々な分野で行われ ており，その発展にはめざましいものがある。特に関 心の高まりつつあるファジィ・エキスパートシステム (FES) は, ファジィ制御を中心に実用例が登場してお り，他分野への応用が期待されている。

我々は, オムロン・ライフサイエンス研究所(侏)と共 同で, FESの応用として総合健康管理支援エキスパー トシステムの開発に取り組んできたが, その中で, 貧 血, 肝機能障害, 高脂血症, 高尿酸血症, 而糖能障害, 腎機能障害, 高血圧, 肥満, 心電図, その他の画像検 查等約 20 程の判定領域に関する自動判定システムを 開発し, 満足すべき結果を得たのでその一例としてフ アジィ推論による肝機能障害自動判定の成績について 報告する。

〈対象及び方法〉対象は, 肝生検により病理診断の 判明している 78 症例で, 大分類 3 病態, 中分類 11 病
態，小分類 17 病態である。これらの症例について，ま ず，本システムの判定能力を評価する目的で，診断時 の血液生化学検查デー夕（最高 19 項目, 最低 3 項目, 平均検査項目数 8.6), 肥満度と性・年齢等の問診情報 を入力しシミュレーションを行った。肝機能障害判定 ルールとしては, 51 ルール作成されている。次に, 健 診等でしばしば見られる欠測データによる影響に対す る抵抗性を検討する目的で, GOT, GPT, $\gamma$-GTP の 三種以外のデー夕を人為的に全て削除して同様のシミ ユレーションを行った。これらの判定結果と病理診断 との合致率を大・中・小分類それぞれに対して求め比 較した。

\section{〈結 果〉}

1）病態によっても若干の差を認めるが，第一位診 断の一致率は，大分類で $93.6 \%$ ，中分類で 80.8 $\%$, 小分類に対して $76.9 \%$ であった。又確定度の 近接した第二位診断を含めるとそれぞれ $94.9 \%$, $88.5 \%, 87.2 \%$ とさらに高い一致率であった。

2) GOT, GPT, $\boldsymbol{\gamma}$-GTP の三項目だけであっても, 中分類に対し $65.3 \%$ の致率を保持し,第二位診 断まで含めると $84.6 \%$ でほとんど差を認めない。 但し，確定度は，0.2 低下した。

〈考 察〉脂肪肝であるか慢性肝炎であるかという 鑑別は，保健指導を行う上で，その対応が全く異なる ため重要である。肝機能が基準值内だから正常だとか 超えているから異常だといった判定では不充分であ り，より質的なスクリーニングが求められており，特 に，充分でないデー夕によって健康管理を行わねばな らない健診において, ファジィ推論を応用した本シス テムは，極めて有効的である。しかし，本システムの 特徵は, その高い診断率にあるのではなく,むしろ医 師の診断知識を忠実に取り込むことができることにあ り又知識ベースのメインテナンスの簡便さにある。

Fuzzy Inference and its Application to the Automated Multiphasic Health Testing and Service System (財)京都工場保健会

*オムロン・ライフサイエンス研究所(侏) 